\title{
The Impact of High Temperature on the Development and Quality of In Vitro Matured Beef Cattle Oocytes and Their Potential to Subsequent Embryonic Development
}

\section{Nkadimeng Marble ${ }^{1,2 *}$, van Marle-Köster ${ }^{2}$, Lekola Kgomotso ${ }^{4}$, Mphaphathi Masindi Lotus ${ }^{1}$, Lehloenya Khoboso Christina ${ }^{4}$, Pilane Cyril Mpho $^{1}$, Nedambale Tshimangadzo Lucky ${ }^{1,3}$}

\begin{abstract}
${ }^{1}$ Agricultural Research Council, Animal Production Institute, Germplasm Conservation and Reproductive Biotechnologies, Private bag X2, Irene 0062, South Africa; ${ }^{2}$ Department of Animal and Wildlife Sciences, University of Pretoria, Private bag X20, Hatfield 0028, South Africa; ${ }^{3}$ Tshwane University of Technology, Faculty of Science, Department of Animal Sciences, Private bag X680; ${ }^{4}$ Department of Agriculture, University of Zululand, Private Bag X1001, KwaDlangezwa 3886, South Africa.
\end{abstract}

\begin{abstract}
The study aimed to evaluate the effect of high temperature on cattle oocytes matured in vitro at 39, 41, 42, $43^{\circ} \mathrm{C}$ and to evaluate apoptosis through Caspase-activity and DNA fragmentation on produced embryos. Cumulus oocyte complexes (COC) were matured at $39,41,42$ and $43^{\circ} \mathrm{C}$. Two best maturation temperatures were selected for maturation throughout embryo production. Post maturation, matured oocytes were exposed to standard embryonic conditions. Embryos were evaluated at 3 stages: $\geq 2-4$ cell, $\geq 8$ cell and blastocyst to determine Caspase- 3 activity and DNA fragmentation. Maturation of oocytes at 41 and $39^{\circ} \mathrm{C}$ demonstrated no significant difference $(p>0.05)$ however, higher maturation rate compared to 42 and $43^{\circ} \mathrm{C}$. Matured oocytes at 39 and $41^{\circ} \mathrm{C}$ showed no difference $(p>0.05)$ in embryo development. Blastocysts at $39^{\circ} \mathrm{C}$ maturation had higher $(p<0.05)$ nuclei cells compared to those at $41^{\circ} \mathrm{C}$. Caspase- 3 activity was comparable at $\geq 2-4$ cell and $\geq 8$ cell for both 39 and $41^{\circ} \mathrm{C}$ maturation temperatures, however, $41^{\circ} \mathrm{C}$ showed high DNA fragmentation compared to $39^{\circ} \mathrm{C}$ maturation group. Blastocyst from oocytes matured at $41^{\circ} \mathrm{C}$ had higher Caspase-3 activity and DNA fragmentation than those at $39^{\circ} \mathrm{C}$. Embryos derived from $41^{\circ} \mathrm{C}$ maturation temperature resulted in evidence of apoptosis compared to $39^{\circ} \mathrm{C}$.
\end{abstract}

Keywords | Oocyte maturation, High temperature, Embryos, Cell apoptosis, Blastocyst

Received | May 17, 2021; Accepted | October 09, 2021; Published | December 13, 2021

*Correspondence | Nkadimeng Marble, Agricultural Research Council, Animal Production Institute, Germplasm Conservation and Reproductive Biotechnologies, Private bag X2, Irene 0062, South Africa; Email: Nkadimenglm@gmail.com

Citation | Marble N, Marle-Köster V, Kgomotso L, Lotus MM, Christina LK,Mpho PC, Lucky NT (2022). The impact of high temperature on the development and quality of in vitro matured beef cattle oocytes and their potential to subsequent embryonic development. Adv. Anim. Vet. Sci. 10(1): 183-191.

DOI | http://dx.doi.org/10.17582/journal.aavs/2022/10.1.183.191

ISSN (Online) | 2307-8316; ISSN (Print) | 2309-3331

Copyright (C) 2022 Lukkananukool et al. This is an open access article distributed under the Creative Commons Attribution License, which permits unrestricted use, distribution, and reproduction in any medium, provided the original work is properly cited.

\section{INTRODUCTION}

$T$ o date in vitro production and developmental rate of cattle embryos attained a great deal of attention (Sakatini, 2017; Kidie, 2019). The technique is widely implemented by animal breeders around the world to accelerate animal genetics for improved animal production and livestock sustainability (Hafez, 2015; Blondin, 2015).
However, in South Africa (SA) the viability of cattle embryos produced in vitro over the past decade has been reported to be less viable than the in vivo counterparts (Arlotto et al.,2001; Mapeka et al., 2019). Additionally, this technology has not yet been widely used in most African countries with the global in vitro embryo production (IVEP) statistics reporting a $3.51 \%$ adoption of the technique as compared to $98 \%$ implementation in North 
America and $71.7 \%$ in European countries (IETS, 2015; Perry 2018; Kidie, 2019).

Amongst other advantages, the IVEP technology is one of the embryo biotechnologies that plays a crucial role in evaluating heat stress mechanisms (Bó et al., 2019). The artificial culture environment of IVEP allows investigation of the quality of oocytes and embryos at a preferred temperature such as the maternal temperature during hot summer months (Sakatini, 2017). Heat stress has been reported to compromise the competence of embryos in different developmental stages from maturation to subsequent development (Hanson, 2009; Payton et al., 2018). It alters Luieternizing (LH) and Follicular stimulating hormone $(\mathrm{FSH})$ secretion required for follicular function (Paula-lopes and Hansen, 2002; Wolfenson and Roth, 2019). Alterations of these hormones can result in the delay of ovulation and aged oocyte that has low fertilization rate and poor quality embryos (A1Katanani et al., 2002). The report by van Wettere et al. (2021) demonstrated that heat stress affects follicular development and growth, furthermore impair nuclear maturation on in vitro cattle oocytes.

During oocyte maturation, heat stress further disrupts chromosome alignment, decreases oocytes number reaching metaphase II and induces oocyte apoptosis (Hansen, 2009). In the early stages of embryo development, heat stress results in organellar damage as a result of microfilament and microtubule disruption, and mitochondrial swelling (Payton et al., 2018; Sakatani, 2017). Studies have shown that heat stress activates apoptosis in oocytes and embryos by releasing oxidative stress agents in the mitochondria and disrupts the mitochondrial function (Sakatani, 2017). Apoptosis occurs due to the release of the DNAse enzyme that cuts dsDNA and generates 3-hydroxy ends through activation of caspases of the cysteine proteases family (Somal et al., 2015).

High temperature due to climate change has affected livestock production worldwide (Rojas-Downing et al., 2017). In SA, extremely high temperatures reaching $43^{\circ} \mathrm{C}$ with 12 heat waves in 71 days were evident primarily in the Northern, Central and the East coastal regions during December-February summer months of 2015/2016 (Scholtz et al., 2016; Mbokodo et al., 2020). Moreover, estimations of 1.5 to $3^{\circ} \mathrm{C}$ in temperature increase is expected in 2050 as a result of climate changes (Department of Environmental Affairs, 2010). This may affect the fertility of beef cattle enormously.

South African indigenous breeds such as Nguni, Bosmara and Boran are known to be adaptable to harsh conditions such as extreme temperatures (Mapiye et al., 2008; Katiyatiya et al., 2017). However, the $2015 / 2016$ drought resulted in a decline in beef cattle productivity and high mortality in the affected provinces (Mthembu and Zwane, 2017). It is therefore vital to understand "how heat stress affects the competence and development of beef cattle oocytes and embryos in SA breeds". Thus, in SA no information is available on the evaluation of heat stress on cattle embryos in beef cattle breeds. Furthermore, there are limited studies on the physiological changes of oocytes competency at higher temperatures equivalent to most of the South African summer temperatures such as $43{ }^{\circ} \mathrm{C}$. Therefore, the IVEP study evaluates the high temperature on embryo development in all the embryo production stages and the link between heat stress and cell apoptosis on the produced embryos.

\section{MATERIALS AND METHODS}

\section{OOCYTES COLLECTION}

Beef cattle ovaries (Nguni, Bonsmara and Brahman) were received from a local abattoir (Morgan). Ovaries were transported within an hour to the laboratory at 38 ${ }^{\circ} \mathrm{C}$ in buffer saline (Sigma Aldrich ${ }^{\circledast}$, Germany). At arrival, fresh pre-warmed buffer saline was used to wash ovaries for removal of blood contamination and further sprayed with $70 \%$ alcohol for any preclusion of contamination. Aspiration method was used to retrieve oocytes according to Bohlooli et al. (2015). A total of 777 oocytes were utilized for in vitro maturation procedure to find the best suitable maturation temperatures throughout the study and 982 oocytes were used for subsequent embryo production experiments Figure 1.

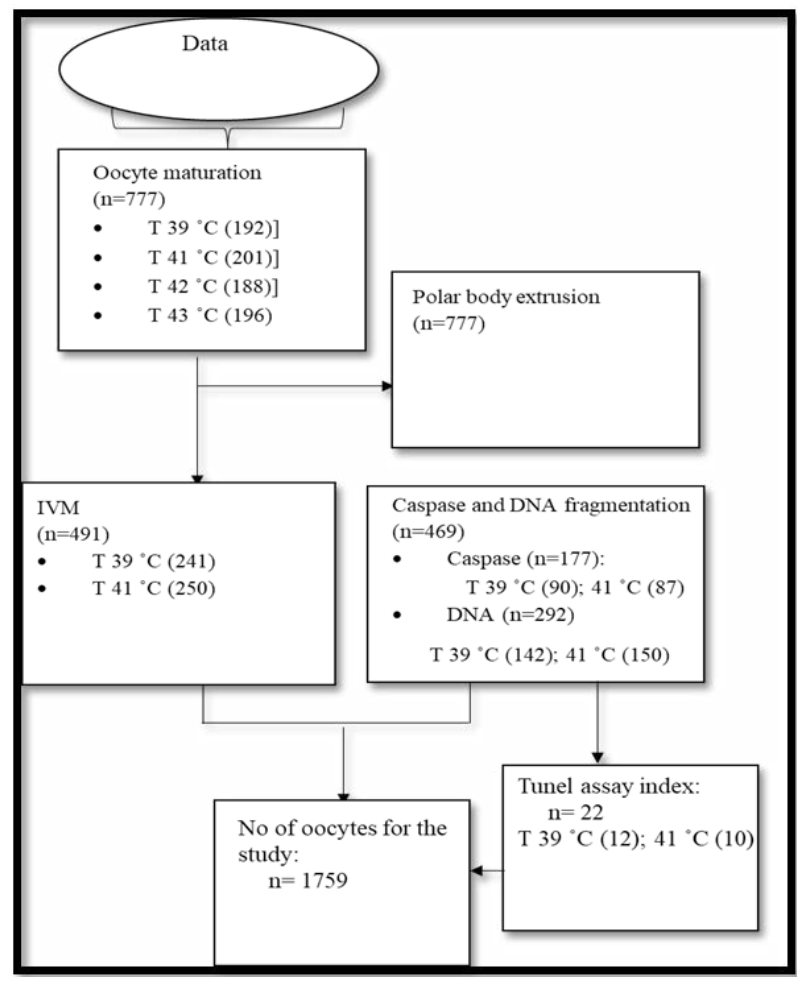

Figure 1: Flow of data collected in the study period. 


\section{IN VITRO MATURATION OF OOCYTES}

Post oocytes retrieval, cumulus oocyte complexes (COCs) with $\geq 3$ layers of cumulus cells (Şen and Kuran, 2018) were selected under the Olympus CX 23 microscope at 80x magnification (New York microscope Co, USA). Three $\mathrm{ml}$ of modified Dulbecco phosphate buffer saline (DPBS) (lifetechnologies ${ }^{\circledR}$, South Africa) and tissue culture medium [M-199 + 10\% Fetal bovine serum (FBS)] (Sigma Aldrich ${ }^{\circledR}$, Germany) were used to wash selected COCs. In each medium COCs were washed two times. The COCs were allocated randomly into four temperature groups: $39,41,42$ and $43{ }^{\circ} \mathrm{C}$ (50 oocytes per 4 maturation wells for each incubation temperature). The universal M-199 medium was used for maturation of COCs. The medium was supplemented with $40 \mu \mathrm{FSH}, 20 \mu \mathrm{LH}$ and $20 \mu \mathrm{l}$ Estradiol (EST) (Sigma Aldrich ${ }^{\circledR}$, Germany) and covered with $250 \mu 1$ of mineral oil (Sigma Aldrich ${ }^{\circledR}$, USA). COCs were matured at $5 \% \mathrm{CO}_{2}, 5 \% \mathrm{O}_{2}$, and $90 \% \mathrm{~N}_{2}$ at $100 \%$ humidified air for 24 hours. Post 24-hour (h) incubation, polar body extrusion was examined. Polar body extrusion was used as a maturation parameter according to Şen and Kuran (2018). In each temperature, oocytes were examined for polar body extrusion. Briefly, oocytes were submerged in $200 \mu \mathrm{l}$ M-199 medium supplemented with FBS (Sigma Aldrich ${ }^{\circledR}$, Germany) (M-199 + 10 \% FBS, Sigma Aldrich ${ }^{\circledR}$, Germany) and vortexed for a minute and 30 seconds. Olympus 1x 71 microscope (New York microscope Co, USA) was used to assess polar bodies at $20 \mathrm{x} / 0.45 \mathrm{Rc} 2$ magnification. The selection of two temperatures (39 and $41{ }^{\circ} \mathrm{C}$ ) for subsequent embryonic development were due to polar bodies examination outcomes. Embryonic development proceeded to normal conditions $\left(39{ }^{\circ} \mathrm{C}\right.$ incubation temperature, $5 \% \mathrm{CO}_{2}, 5 \% \mathrm{O}_{2}$, and $90 \% \mathrm{~N}_{2}$ at $100 \%$ humidified air).

\section{IN VITRO FERTILIZATION AND CULTURE}

Preparation OF MATURED OOCYTES FOR IN VITRO FERTILIZATION

In vitro fertilization commenced with oocyte wash in 5 drops of $100 \mu \mathrm{l}$ pre-warmed Bracket and Oliphant (BIOIVF) medium covered with $250-\mu \mathrm{l}$ mineral oil (Sigma Aldrich $^{\oplus}$, USA). Oocytes were transferred to seven drops of $50 \mu \mathrm{l}$ pre-warmed Bio-IVF medium (20-25 oocytes) covered with $250 \mu \mathrm{l}$ of mineral oil (Sigma Aldrich ${ }^{\circledast}, \mathrm{USA}$ ) for fertilization.

\section{SEMEN THAWING}

Oocytes were fertilized by frozen-thawed Nguni semen in $0.25 \mathrm{ml}$ straw size. The thawing procedure proceeded with semen in air for 30 seconds and in warm water of $37^{\circ} \mathrm{C}$ for one minute. Thawed semen was washed through centrifugation two times in $4 \mathrm{ml}$ of pre-warmed sperm wash medium (Sigma Aldrich ${ }^{\oplus}$, USA) at 1500 RPM for 8 minutes per centrifugation. During second centrifugation, previous sperm wash medium was removed and new 4 $\mathrm{ml}$ sperm wash medium was added to proceed with the centrifugation. Post second centrifugation, $50 \mu \mathrm{l}$ sperm wash $\mathrm{X}$ number of fertilization drops was added to the sperm pellet. A total of 20-25 matured oocytes in each drop of Bio-IVF medium (Sigma Aldrich ${ }^{\otimes}$, USA) was then fertilized with $50 \mu \mathrm{l}$ sperm pellet at a concentration of $0.98 \times 10^{6}$ sperm cells $/ \mathrm{ml}$ and incubated for 18 hours (Seshoka et al., 2016).

\section{IN VITRO CULTURE}

Post 18 hours of insemination, cumulus cells on presumptive zygotes were removed through vortex for one minute and 30 seconds in $200 \mu \mathrm{l}$ of pre-warmed [M199+10\% FBS (Sigma Aldrich $\left.\left.{ }^{\oplus}, \mathrm{USA}\right)\right]$ medium. Five drops of $100 \mathrm{ml}$ prewarmed synthetic oviductal fluid medium supplemented with bovine serum albumen [SOF-BSA (Sigma Aldrich ${ }^{\oplus}$, USA)] covered with $250 \mu 1$ mineral oil was used to wash zygote prior in vitro culture. Zygotes (20-25) were cultured in a modular chamber that contained $5 \%$ oxygen and $\mathrm{CO}_{2}$ mixed gas added for 48 hours at $39{ }^{\circ} \mathrm{C}$ incubation temperature and $100 \%$ humidity. Cleavage was examined at 48 hours of incubation. Post 48 hours, embryos were transferred to pre-warmed synthetic oviductal fluid supplemented with FBS [SOF-FBS (Sigma Aldrich" USA)] and further incubated for 72 hours. At $72 \mathrm{~h}$, a minimum of $20 \mu 1$ of [(SOF-FBS (Sigma Aldrich ${ }^{\circledast}$, USA) ] old medium was removed and replaced with pre-warmed fresh medium of the same amount in each drop. Blastocyst were evaluated at day seven of embryo production (Bryla and Trzcińska, 2011).

\section{NUCLEI CELL ANALYSIS OF PRODUCED BLASTOCYST}

Expanded and hatched blastocysts were examined for nuclei cell count per maturation group (39 and $41^{\circ} \mathrm{C}$ ). Blastocysts were removed and washed twice in $3 \mathrm{ml}$ of pre-warmed DPBS medium (lifetechnologies ${ }^{\circledast}$, South Africa). Blastocysts were stained using Hoechst (33342) (Sigma Aldrich ${ }^{\circledast}$, Isreal) solution and transferred to a sterile microscope glass slide (Labcon, Germany). Four square points of Vaseline was added surrounding the blastocyst on the glasslide and the coverslip was placed on top of the four Vaseline pointers. An amount of $5 \mu \mathrm{l}$ Hoechst solution (33342) was gently added on each side of the coverslip (Labcon, Germany) to cover the whole area under the slip. The coverslip was then moderately pressed until it touches the embryo drop and sealed with a colourless nail polish (Essence, New York). The staining and mounting procedure was performed with dimmed lights (Bohlooli et al., 2015). Computer sperm analyser ${ }^{\circledR}$ v 3.4.0 english version (Microptic, Spain) and Olympus B X51 epifluorescence was used to evaluate Nuclei cell at 60x magnification. 
Caspase-3 activity evaluation of produced EMBRYOS.

Embryos produced from oocytes at 39 and $41^{\circ} \mathrm{C}$ maturation temperature were removed at day two ( $\geq 2-4$ cell), day five ( $\geq 8$ cell) and day seven (blastocyst) of embryo production for evaluation of Caspase-3 activity. Drops of $50 \mu \mathrm{l}$ prewarmed phosphate buffer saline-polyvinylpyrrolidone (PBS-PVP) (Sigma Aldrich ${ }^{\circledR}$, Germany) was used to wash all embryos prior the Caspase- 3 activity procedure. The procedure was performed using Caspase-3 Colorimetric Activity Assay Kit (EMD Millipore, USA). Prior the procedure positive control samples were incubated in 50 $\mu \mathrm{l}$ drops of hydrogen peroxide $\left(\mathrm{H}_{2} \mathrm{O}_{2}\right)$ (Sigma Aldrich ${ }^{\circledR}$, Germany) for two hours. The reactions of enzyme were monitored with 96 microtiter Thermo scientific plate reader (Power Wave XS; BioTek, USA) at $405 \mathrm{~nm}$ and 450 $\mathrm{nm}$ reference filter through the OD readings (Optimal density) values (Hwang et al., 2012).

\section{TUNELASSAYPROCEDUREFORDNAFRAGMENTATION}

\section{ON PRODUCED EMBRYOS FROM OOCYTES MATURED AT} 39 AND $41^{\circ} \mathrm{C}$

Produced embryos were removed and washed using a similar procedure as in the Caspase-3 activity experiment. Embryos were permeabilized in $50 \mu$ drop of $0.5 \%(\mathrm{v} / \mathrm{v})$ Triton X-100 (Sigma Aldrich ${ }^{\circledR}$, USA), $0.1 \%(\mathrm{w} / \mathrm{v}$ ) and sodium citrate (Sigma Aldrich ${ }^{\circledR}$, USA) solution incubated for 30 minutes. Embryos were fixed in $50 \mu \mathrm{l}$ drops of 4 $\%$ paraformaldehyde (Sigma Aldrich ${ }^{\circledR}$, USA) solution for one hour at room temperature prior permeabilization. After fixation, embryos were washed 3 times in $50 \mu \mathrm{l}$ drop of PBS/ PVP (Sigma Aldrich ${ }^{\circledR}$, Germany) and incubated for 30 minutes to permeabilize. Embryos were stored for 30 min at room temperature in a humidified box post permeabilization prior TUNEL assay procedure (Silva et al., 2013).

Post preparation of all embryos, samples continued to the Alexa Fluor ${ }^{\circledR} 488$ Click-iT $^{\circledR}$ TUNEL assay kit (Eugen, USA) according to the manufacturer's instruction for the examination of fragmented DNA. Post completion of the TUNEL assay, all samples, were mounted on a slide and covered with a coverslip in a parallel procedure performed on blastocyst nuclei cell analysis experiment for imaging. TUNEL index was also performed on produced blastocysts from both maturation groups $\left(39\right.$ and $41^{\circ} \mathrm{C}$ ) to evaluate the percentage of fragmented nuclei. Click-iT ${ }^{\circledR}$ TUNEL assay (Eugen, USA) was used for determining the apoptotic nuclei. The total nuclei number was determined by Hoechst (33342) stain and nuclei cells were recorded as positive for TUNEL assay procedure when they had visible green fluorescence from Alexa 488-stain. The nuclei fragmented percentage was done by TUNEL index $=($ no. TUNEL-positive nuclei, fragmented and condensed)/ (total no. of nuclei) $\times 100$ (Bryla and Trzcińska, 2011). The same procedure in blastocyst nuclei cell analysis was performed for analysis of stained embryos.

\section{STATISTICAL ANALYSIS}

Data for polar body status, embryo production, Caspase-3 activity and DNA fragmentation was analyzed as a complete randomized design. Polar body data comprised 4 treatments $\left(39,41,42\right.$ and $43{ }^{\circ} \mathrm{C}$ ) replicated four times. Embryo production, Caspase- 3 activity and DNA fragmentation were replicated four times with two treatments $\left(39\right.$ and $\left.41{ }^{\circ} \mathrm{C}\right)$. An appropriate Analysis of Variance (ANOVA) was performed. Shapiro-Wilks test was used on the standardized residuals to test for deviations from normality (Shapiro and Wilk, 1965). Means of significant effects were compared using Student's t-LSD (Least Significant Differences) at the 5\% level of significance. All the above analyses were performed using SAS 9.2 Statistical Software (SAS, 1999).

\section{RESULTS}

\section{IN VITRO MATURATION OF OOCYTES FROM FOUR} DIFFERENT MATURATION TEMPERATURES

Extrusion of polar body demonstrated no difference $(p>0.05)$ between oocyte maturation at 41 and $39^{\circ} \mathrm{C}$ incubation temperature. However, 42 and $43{ }^{\circ} \mathrm{C}$ had lower extrusion of polar bodies ( $\mathrm{p}<0.05)$ than 39 and $41^{\circ} \mathrm{C}$ (Table 1). Figure 2 illustrates images of oocytes matured at four temperatures $\left(39,41,42\right.$ and $\left.43^{\circ} \mathrm{C}\right)$.

Table 1: Polar body extrusion of cattle oocytes matured at $39,41,42$ and $43^{\circ} \mathrm{C}$ incubation temperatures (Mean $\pm \mathrm{SD}$ ).

\begin{tabular}{llll} 
Treatment & $\begin{array}{l}\text { Oocytes } \\
\text { (no) }\end{array}$ & $\begin{array}{l}\text { \% of Polar } \\
\text { body }\end{array}$ & $\begin{array}{l}\text { \% of Non-polar } \\
\text { body }\end{array}$ \\
\hline $39{ }^{\circ} \mathrm{C}$ & 192 & $57.3 \pm 1.0^{\mathrm{a}, \mathrm{b}}$ & $42.1 \pm 1.5^{\mathrm{b}}$ \\
\hline $41^{\circ} \mathrm{C}$ & 201 & $60.0 \pm 1.2^{\mathrm{a}}$ & $40.1 \pm 1.9^{\mathrm{b}}$ \\
\hline $42^{\circ} \mathrm{C}$ & 188 & $20.5 \pm 1.0^{\mathrm{b}}$ & $60.3 \pm 4.8^{\mathrm{a}}$ \\
$43^{\circ} \mathrm{C}$ & 196 & $10.3 \pm 1.0^{\mathrm{b}}$ & $80.8 \pm 1.0^{\mathrm{a}}$ \\
\hline
\end{tabular}

a, b mean within columns with different superscripts differ at $(p<0.05)$. Non-polar body= the number of oocytes presented without extrusion of polar body post $24 \mathrm{~h}$ maturation.

IN VITRO EMBRYO PRODUCTION AND BLASTOCYST EVALUATION FROM OOCYTES MATURED AT 39 AND $41^{\circ} \mathrm{C}$ Table 2 represents produced embryos at different in vitro embryo production stages and nuclei cell count of produced blastocyst from oocytes matured at 39 and $41^{\circ} \mathrm{C}$. Produced blastocysts at day 7 from oocytes matured at two temperatures 39 and $41^{\circ} \mathrm{C}$ and images of Hoechst (33342) stained blastocysts from 39 and $41^{\circ} \mathrm{C}$ maturation temperatures are presented in Figure 1 . There was no difference $(p>0.05)$ on all the embryonic developmental stages between 39 and $41^{\circ} \mathrm{C}$. Blastocyst from oocytes matured at $39^{\circ} \mathrm{C}$ had higher $(p<0.05)$ nuclei cell number 
than blastocyst of oocytes matured at $41^{\circ} \mathrm{C}$.

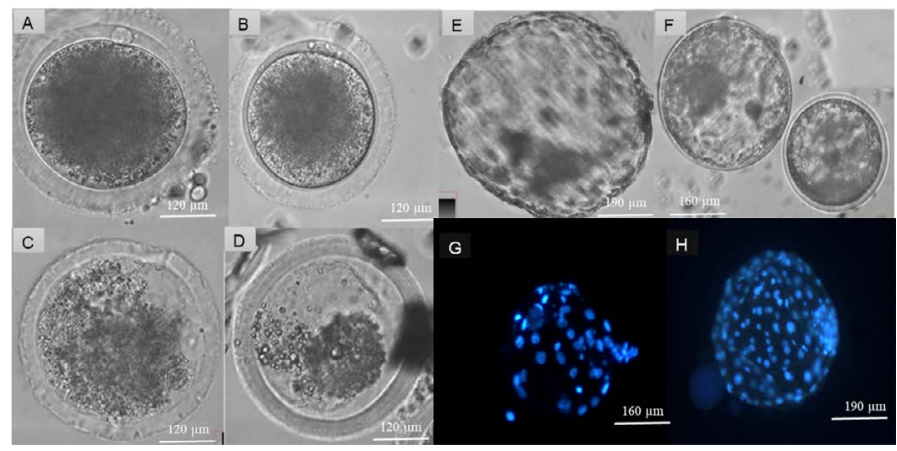

Figure 2: Assessment of heat stress on cattle oocytes at four temperatures: $39,41,42$ and $43{ }^{\circ} \mathrm{C}$. Produced blastocyst at day 7 and Hoechst (33342) staining of nuclei cells of produced blastocysts. Suitable maturation temperatures were selected according to the extrusion of polar bodies at a significant of $(P<0.05)$. Matured cattle oocytes from $(\mathrm{A})$ $39^{\circ} \mathrm{C}$, (B) $41^{\circ} \mathrm{C}$, (C) $42{ }^{\circ} \mathrm{C}$ and (D) $43^{\circ} \mathrm{C}$. Day 7 Blastocyst from cattle oocytes matured at $(\mathrm{E}) 39^{\circ} \mathrm{C}$ and $(\mathrm{F}) 41^{\circ} \mathrm{C}$, Hoechst 33342 (Blue) stained blastocyst from $(\mathrm{G}) 41^{\circ} \mathrm{C}$ and $(\mathrm{H}) 39^{\circ} \mathrm{C}$ matured cattle oocytes.

Table 2: In vitro embryo development from cattle oocytes matured at $39^{\circ} \mathrm{C}$ and $41^{\circ} \mathrm{C}$ incubation temperatures (Mwan $\pm \mathrm{SD})$.

\begin{tabular}{lllllll}
\multicolumn{7}{c}{ Cleavage rate (\%) } \\
$\begin{array}{lllllll}\text { Tem- } \\
\text { perature cytes }\end{array}$ & $\begin{array}{llllll}\text { No oo- } \\
\text { (d2) }\end{array}$ & $\begin{array}{l}8 \text { cell } \\
\text { (d2) }\end{array}$ & $\begin{array}{l}\text { Morula } \\
\text { (d5) }\end{array}$ & $\begin{array}{l}\text { Blasto- } \\
\text { cyst (D7) }\end{array}$ & $\begin{array}{l}\text { Cell nu- } \\
\text { clei (n) }\end{array}$ \\
$39^{\circ} \mathrm{C}$ & 241 & $65.0 \pm$ & $39.2 \pm$ & $19.0 \pm$ & $11.4 \pm$ & $133 \pm$ \\
& & $6.8^{\mathrm{a}}$ & $6.6^{\mathrm{a}}$ & $14.16^{\mathrm{a}}$ & $2.6^{\mathrm{a}}$ & $57.9^{\mathrm{a}}$ \\
$41^{\circ} \mathrm{C}$ & 250 & $62.4 \pm$ & $35.0 \pm$ & $15.2 \pm$ & $11.2 \pm 6.3^{\mathrm{a}}$ & $45.8^{ \pm}$ \\
& & $6.5^{\mathrm{a}}$ & $6.4^{\mathrm{a}}$ & $4.8^{\mathrm{a}}$ & & $11.2^{\mathrm{b}}$
\end{tabular}

CASPASE-3 ACTIVITY OF PRODUCED EMBRyOS FROM OOCYTES MATURED AT 39 AND $41^{\circ} \mathrm{C}$

Embryos at $\geq 2-4$ cell and $\geq 8$ cell from oocytes matured at both 39 and $41^{\circ} \mathrm{C}$ showed no differences $(p>0.05)$ on Caspase- 3 activity (Table 3 ). However, Caspase- 3 activity was higher $(p<0.05)$ on blastocyst produced from at $41^{\circ} \mathrm{C}$ matured oocytes compared to oocytes matured at $39^{\circ} \mathrm{C}$.

Table 3: Caspase-3 activity on different stages of produced cattle embryos in vitro (Mean \pm SD).

\begin{tabular}{|l|l|l|l|l|l|}
\hline $\begin{array}{l}\text { Tempera- } \\
\text { ture }\end{array}$ & $\begin{array}{l}\text { Embry- } \\
\text { os (no) }\end{array}$ & $\begin{array}{l}\text { Positive } \\
\text { control }\end{array}$ & $\begin{array}{l}\geq 2-4 \text { cell } \\
\text { embryo }\end{array}$ & $\begin{array}{l}\geq 8 \text { cell } \\
\text { embryo }\end{array}$ & $\begin{array}{l}\text { Blasto- } \\
\text { cyst }\end{array}$ \\
\hline $39^{\circ} \mathrm{C}$ & 90 & $0.815 \pm$ & $0.015 \pm$ & $0.022 \pm$ & $0.037 \pm$ \\
& & 0.049 & $0.001^{\mathrm{a}}$ & $0.007^{\mathrm{a}}$ & $0.012^{\mathrm{b}}$ \\
$41^{\circ} \mathrm{C}$ & 87 & & $0.016 \pm$ & $0.032 \pm$ & $0.053 \pm$ \\
& & & $0.002^{\mathrm{a}}$ & $0.013^{\mathrm{a}}$ & $0.005^{\mathrm{a}}$ \\
\hline
\end{tabular}

a,b mean within columns with different superscripts differ at $(p<0.05)$.Assessment of Caspase- 3 activity on $\geq 2-4$ cell,$\geq 8$ cell and blastocysts embryos of oocytes subjected to heat stressed (41 $\left.{ }^{\circ} \mathrm{C}\right)$. The measurement of absorbance was by reading $\mathrm{OD}=$ optimal density at $405 \mathrm{~nm}$ and $450 \mathrm{~nm}$ reference filter using a microplate reader.
TUNEL ASSAY EVALUATION ON PRODUCED EMBRYOS FROM OOCYTES AT 39 AND $41^{\circ} \mathrm{C}$ MATURATION TEMPERATURE

Significantly higher $(p<0.05)$ DNA fragmentation was observed in $\geq 2-4$ cell embryos from $41^{\circ} \mathrm{C}$ compared to $39{ }^{\circ} \mathrm{C}$. Embryos at $\geq 8$ cell had higher TUNEL positives $(p<0.05)$ at $41{ }^{\circ} \mathrm{C}$ compared to embryos produced from oocytes at $39^{\circ} \mathrm{C}$. The was no significant difference $(p>0.05)$ on TUNEL positives between embryos at $\geq 2-4$ cell and $\geq 8$ cell from $39^{\circ} \mathrm{C}$ incubation temperature (Table 4). The $41^{\circ} \mathrm{C}$ maturation temperature on produced blastocyst showed higher $(\mathrm{p}<0.05)$ percentage of fragmented DNA compared to $39^{\circ} \mathrm{C}$ (Table 5). Figure 3, illustrates stained $\geq$ 2-4 cell, $\geq 8$ cell embryos and images of stained blastocyst post TUNEL assay procedure from both temperatures groups ( 39 and $41^{\circ} \mathrm{C}$ ).

Table 4: DNA fragmentation of nuclei using TUNEL assay at different embryonic stages (Mean \pm SD).

\begin{tabular}{|lllll}
$\begin{array}{l}\text { Tempera- No em- } \\
\text { ture } \\
\text { bryos }\end{array}$ & $\begin{array}{l}\text { Embryo } \\
\text { group }\end{array}$ & $\begin{array}{l}\text { Tunel posi- } \\
\text { tive (\%) }\end{array}$ & $\begin{array}{l}\text { Tunel nega- } \\
\text { tive (\%) }\end{array}$ \\
\hline $39^{\circ} \mathrm{C}$ & 77 & $\geq 2-4$ cell & $10.8 \pm 1.2^{\mathrm{c}}$ & $89.2 \pm 4.8^{\mathrm{a}}$ \\
& 65 & $\geq 8$ cell & $19.6 \pm 1.9^{\mathrm{bc}}$ & $80.5 \pm 2.7^{\mathrm{a}}$ \\
$41^{\circ} \mathrm{C}$ & 80 & $\geq 2-4$ cell & $26.2 \pm 2.9^{\mathrm{b}}$ & $73.8 \pm 4.1^{\mathrm{a}}$ \\
& 70 & $\geq 8$ cell & $63.3 \pm 3.1^{\mathrm{a}}$ & $36.7 \pm 1.6^{\mathrm{b}}$ \\
\hline
\end{tabular}

a,b,c mean value within the rows with different superscripts differ at $(\mathrm{p}<0.05)$.

Table 5: TUNEL assay indexes on in vitro cattle blastocyst $($ Mean \pm SD)

\begin{tabular}{lllll}
$\begin{array}{l}\text { Tempera- Blasto- } \\
\text { ture }\end{array}$ & $\begin{array}{l}\text { Nysts }(\text { no) nuclei } \\
\text { cell }\end{array}$ & $\begin{array}{l}\text { TUNEL } \\
\text { positive } \\
\text { nuclei }\end{array}$ & $\begin{array}{l}\text { TUNEL } \\
\text { indexes } \\
\text { (\%) }\end{array}$ \\
$39^{\circ} \mathrm{C}$ & $12.0 \pm 1.2^{\mathrm{a}}$ & $127.8 \pm 53.4^{\mathrm{b}}$ & $10.3 \pm 4.8^{\mathrm{b}}$ & $9.7 \pm 6.7^{\mathrm{b}}$ \\
$41^{\circ} \mathrm{C}$ & $10.0 \pm 1.4^{\mathrm{a}}$ & $46.2 \pm 10.0^{\mathrm{a}}$ & $21.8 \pm 21.8^{\mathrm{a}}$ & $48.0 \pm 8.2^{\mathrm{a}}$ \\
\hline
\end{tabular}

$a, b$ mean value within the rows with different superscripts differ at $(p<0.05)$. Nuclei cell were recorded as positive for TUNEL labelling when they had visible green fluorescence.

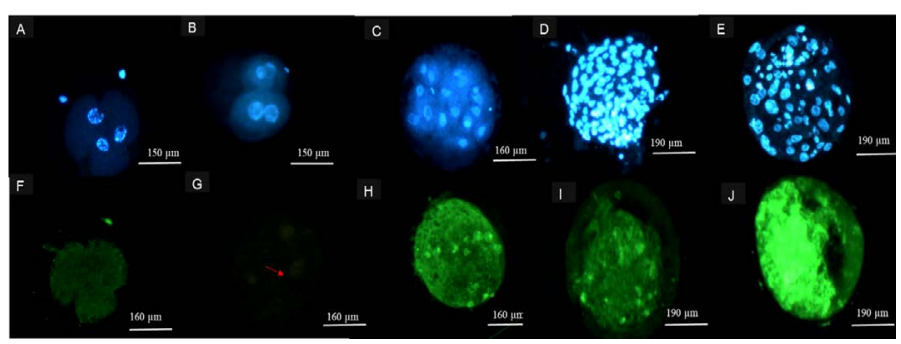

Figure 3: Representation of images following TUNEL Assay procedure. Hoechst 33342 (Blue) stained 2-4 cell embryos from (A) $39^{\circ} \mathrm{C}$, (B) $41^{\circ} \mathrm{C},(\mathrm{C}) \geq 8$ cell embryos from both 39 and $41{ }^{\circ} \mathrm{C}$, blastocysts from cattle oocytes matured at (D) $39^{\circ} \mathrm{C}$ and (E) $41^{\circ} \mathrm{C}$. Alexa 488-stained (green) 2-4 cell embryos from $41(\mathrm{~F}), 39^{\circ} \mathrm{C}(\mathrm{G}), \geq 8$ cell embryos from $41{ }^{\circ} \mathrm{C}(\mathrm{H})$ and Alexa 488-stained (green) blastocysts from cattle oocytes matured at (I) 39 and (J) 41 ${ }^{\circ} \mathrm{C}$ maturation group. 


\section{DISCUSSION}

Exposure of oocytes at high temperature during maturation resulted in cell apoptosis on produced embryos. The maturation experiments demonstrated no significant difference between oocytes matured at 39 and $41^{\circ} \mathrm{C}$, however, 42 and $43^{\circ} \mathrm{C}$ differed respectively in polar body extrusion. There was no difference in subsequent developmental stages (cleavage rate, morula and blastocyst rates) of produced embryos amongst the two maturation groups (39 and $41^{\circ} \mathrm{C}$ ). The number of nuclei on the produced blastocyst differed significantly between the two temperature groups ( 39 and $41^{\circ} \mathrm{C}$ ). The present study showed a relationship between high temperature and cell apoptosis through Caspase- 3 and DNA fragmentation evaluation of embryos matured at $41^{\circ} \mathrm{C}$ on different embryonic stages.

According to Roth and Hansen (2004) and the report by Sakatani (2017), maturation failures are as a result of elevated temperatures within the physiological range of $40-41^{\circ} \mathrm{C}$ during maturation. In contrast to the current study, in vitro maturation resulted in similar polar body extrusion between heat stressed $\left(41^{\circ} \mathrm{C}\right)$ oocytes and oocytes from $39^{\circ} \mathrm{C}$. Rynkowska et al. (2011) suggested that exposure of oocytes or any other cells to stresses such as high temperature activates a set of proteins called heat shock proteins ( $\mathrm{HSPs})$. These proteins maintain cellular homeostasis and protection against environmental stressors. The latter might have had an influence on the survival of oocytes incubated at $41^{\circ} \mathrm{C}$ in the present study. The high non-polar body extrusion at 42 and $43^{\circ} \mathrm{C}$ maturation temperature groups in this study may be due to the reduction in the synthesis of intracellular proteins by 30 to $50 \%$ due to exposure of oocytes to severe heat (Saeki et al., 1997). The above statement is parallel to the findings by Payton et al. (2011) that showed a reduction in the level of polyA mRNA in bovine oocytes at $12 \mathrm{~h}$ in vitro maturation due to heat stress. Furthermore, Campen et al. (2018) highlighted that heat stress exposure at 42 ${ }^{\circ} \mathrm{C}$ on oocytes results in the alterations of gap junction communications between oocytes and cumulus cells which consequently interrupt cytoplasmic maturation.

The similarities in embryo development between 39 and $41{ }^{\circ} \mathrm{C}$ maturation temperature in the current study are in line with the work of Sakatani et al. (2015) which emphasized that subsequent embryo development may not be affected by incubation of oocytes at $41{ }^{\circ} \mathrm{C}$ during maturation. Moreover, Silva et al. (2013) reported that the potential of Bos Taurus (Friesian and Brown Swiss) oocytes development during hot season becomes detrimentally reduced than in Bos indicus (Nguni and Brahman) cows. The genetic deposition of the Bos Indicus cattle allows them to have a protective mechanism against heat stress than Bos Taurus cattle (Friesian and Brown Swiss) (Silva et al., 2013). Therefore, the above statement might have an influence in the similarities observed on embryo development between oocytes matured at 41 and $39^{\circ} \mathrm{C}$.

The current study further demonstrated that embryos produced from heat stressed oocytes have the ability to develop to advanced stages of embryo development. Therefore, the produced day 7 blastocysts in the current study from oocytes matured at $41{ }^{\circ} \mathrm{C}$ were examined for their developmental quality through assessment of nuclei cell number. The findings were in line with the work of Sakatani et al. (2004) however, differed with the report by Sakatani et al. (2015). Sakatani et al. (2015) revealed no difference in the inner cell mass ratio and trophectoderm cell of blastocyst previously exposed to heat stress at the early stages of oocyte development. The low nuclei cell number of the heat stress blastocyst in this study might be due to the decrease in trophectoderm cell number. It is considered that at metaphase II of the oocyte life heat stress affects the quality of the trophectoderm cells from produced blastocysts (Ju et al., 2005; Habeeb et al., 2018). Furthermore, the report by Ascari et al. (2017) and Stamperna et al. (2020) demonstrated that the build-up of apoptosis elements and disruption of gene expression in the inner cell mass of blastocyst is as a result of exposure of oocytes to heat stress for 12 hours during in vitro maturation.

Embryos were affected differently at different stages of development during the evaluation of Caspase-3 activity in the present study. The report of Hansen (2015) emphasized that at 2-4 cell the mitochondria of the embryo becomes resistant to depolarization and inhibition of apoptosis may occur or the presence of apoptosis may become minimum. The above may be the reason for the low activity of Caspase-3 on 2-4 cell embryos in the present study. The study of Roth and Hansen (2004) and a report by Stamperna et al (2021) demonstrated Caspase-3 activity in the cytoplasm of a single blastomere of heat-shocked 4 to 8 cell embryos, morulae and blastocyst compared to control. The present study, however, showed no significant difference at $\geq 8$ cell embryos from oocytes matured at 39 and $41{ }^{\circ} \mathrm{C}$. The similarities of the results are in line with the report by Silvia et al. (2009) which emphasizes that resistance to pro-apoptotic signals may occur during preimplantation stage of cattle embryos. Brad et al. (2007) further reported that mitochondrial membrane in cattle embryos can become artificially depolarized by carbonyl cyanide 3-chlorophenylhydrazone (CCCP). Under such circumstances, Caspase- 9 and Caspase- 3 activation take place however, DNA fragmentation does not transpire.

The TUNEL assay findings in the current study showed lower DNA fragmentation in 2-4 cell stage. These suggest 
that the release of DNase by Caspase in 2-4 cell embryos is at minimal. According to the report by Fear and Hansen (2011) cattle embryos at lower stages of development may remain refractory to apoptotic stimuli compared to 8-16-cell developmental stage. Hence, more TUNEL positive nuclei in the present study were observed from embryos at $\geq 8$ cell than $\geq 2-4$ cell. This may suggest that as development progresses higher temperature in lower developmental stages affect a fraction of the blastomere at later stages of development to become TUNEL positive (Brad et al., 2007). As a result, more fragmented nuclei cells in blastocysts were evident from oocytes at 41 than in $39^{\circ} \mathrm{C}$.

\section{CONCLUSIONS AND RECOMMENDATIONS}

The study showed that high temperature influences oocyte competency and compromises embryo development and survival with evidence cell apoptosis. The results expand on the importance of more implementation of assisted reproduction technologies such as IVF in South Africa to provide a controlled environment for produced embryos. This is to overcome reproductive inefficiency in response to high temperature during summer months. It is further recommended that genetic mechanisms involved in the survival of beef cattle embryos during heat stress from diverse SA genotypes should be evaluated to account for the expected future rise of temperature in SA.

\section{ACKNOWLEDGEMENTS}

The authors would like to acknowledge Technology Innovation Agency (TIA) and Southern African Science Service Centre for Climate Change and Adaptive Land Management, Council for Scientific and Industrial Research (SASCAL) for their financial contributions.

\section{NOVELTY STATEMENT}

To our knowledge, this is the first study in Southern Africa to report heat stress on beef cattle embryos produced in vitro and its effect of cell apoptosis on developmental phases of produced embryos.

\section{AUTHOR'S CONTRIBUTION}

MML, PCM and LK assisted in data collection and designing of the manuscript. VME, NTL, NM and LKC drafted, supervised and evaluated the manuscript content.

CONFLICT OF INTEREST

The authors have declared no conflict of interest.

\section{REFERENCES}

-Al-Katanani YM, Paula-Lopes FF, Hansen PJ (2002). Effect of season and exposure to heat stress on oocyte competence in Holstein cows. J. Dairy Sci., 85: 390-396. https://doi. org/10.3168/jds.S0022-0302(02)74086-1

-Arlotto T, Gerber D, Terblanche SJ, Larsen J (2001). Birth of live calves by in vitro embryo production of slaughtered cows in a commercial herd in South Africa. J. S. Afr. Vet. Assoc., 72: 72-75. https://doi.org/10.4102/jsava.v72i2.620

-Ascari IJ, Alves NG, Jasmin J, Lima RR, Quintão CCR, Oberlender G, Camargo LSA (2017). Addition of insulinlike growth factor I to the maturation medium of bovine oocytes subjected to heat shock: Effects on the production of reactive oxygen species, mitochondrial activity and oocyte competence. Domest. Anim. Endocrinol., 60: 50-60. https://doi.org/10.1016/j.domaniend.2017.03.003

- Blondin P (2015). Status of embryo production in the world. Anim. Reprod. Sci., 12: 356-358.

- Bó GA, Cedeño A, Mapletoft RJ (2019). Strategies to increment in vivo and in vitro embryo production and transfer in cattle. Anim. Reprod., 16:411-422. https:/www.animalreproduction.org/article/5b5a6030f7783717068b4603, https://doi.org/10.21451/1984-3143-AR2019-0042

-Bohlooli SH, Bozoğlu Ş, Cedden F (2015). HEPES buffer in ovary-transportation medium influences developmental competence of cattle oocytes. S. Afr. J. Anim. Sci., 45: 538546. https://doi.org/10.4314/sajas.v45i5.11

- Brad AM, Hendricks EM, Hansen PJ (2007). The block to apoptosis in bovine two-cell embryos involves inhibition of Caspase- 9 activation and Caspase-mediated DNA damage. Reproduction, 134: 789-797. https://doi.org/10.1530/ REP-07-0146

- Bryla M, Trzcińska M (2011). Apoptosis in porcine blastocysts derived from 2-4 cell in vivo produced embryos subsequently cultured in vitro. J. Anim. Sci., 11: 261-271.

- Campen KA, Abbott CR, Rispoli LA, Payton RR, Saxton AM, Edwards JL (2018). Heat stress impairs gap junction communication and cumulus function of bovine oocytes. J. Reprod. Dev., 64: 385-392. https://doi.org/10.1262/ jrd.2018-029

-Department of Environmental Affairs, Republic of South Africa (2010). National climate change response green paper. http://www.environment.gov.za//Documents/ Documents/2010Nov17/ climate_change_greenpaper.pdf

- Fear JM, Hansen PJ (2011). Developmental changes in expression of genes involved in regulation of apoptosis in the bovine preimplantation embry. Biol. Reprod., 84: 43-51. https://doi.org/10.1095/biolreprod.110.086249

- Habeeb AAM, Gad AE, EL-Tarabany AA, Atta MAA (2018). Negative effects of heat stress on growth and milk production of farm animals. J. Anim. Husb. Dairy Sci., 2: 1-12.

- Hafez YM (2015). Assisted Reproductive Technologies in Farm Animals. ICMALPS 2015, Alexandria University, Egypt. https://www.researchgate.net/publication/282943615_ Assisted_Reproductive_Technologies_in_Farm_Animals.

-Hansen PJ (2009). Effects of heat stress on mammalian reproduction. Philos. Trans. R. Soc., 364: 3341-3350. https://doi.org/10.1098/rstb.2009.0131

- Hansen PJ (2015). Early embryonic loss due to heat stress. First Edition. (John Wiley and Sons, Gainesville Florida). Chapter 64. https://doi.org/10.1002/9781118833971.ch64

-Hwang I, Bae H, Cheong H (2012). Mitochondrial and 
DNA damage in bovine somatic cell nuclear transfer embryos. J. Vet. Sci., 14: 235-240. https://doi.org/10.4142/ jvs.2013.14.3.235

-International Embryo Technology Society (2015). Statistics of embryo collection and transfer in domestic farm animals. https://www.iets.org/Portals/0/Documents/Public/ Committees/DRC/IETS_Data_Retrieval_2015_V2.pdf

-JuJ,Jiang S,TsengJK,ParksJE,YangX(2005).Heat shock reduces developmental competence and alters spindle configuration of bovine oocytes. Theriogenology, 64: 1677-1689. https:// doi.org/10.1016/j.theriogenology.2005.03.025

- Katiyatiya CLF, Bradley G, Muchenje V (2017). Thermotolerance, health profile and cellular expression of HSP90AB1 in Nguni and Boran cows raised on natural pastures under tropical conditions. J. Therm. Biol., 69: 8594. https://doi.org/10.1016/j.jtherbio.2017.06.009

- Kidie HA (2019). Review on growth and development of multiple ovulation and embryo transfer technology in cattle. World Sci. News, 127: 191-211.

- Mapeka MH, Pilane CM, Treadwell R, Ng'ambi J, Banga C (2019). Comparison of embryo developmental rates in Nguni, Bonsmara and Boran beef cattle breeds following in vitro fertilization and artificial insemination. Afr. J. Biotechnol., 18: 962-969. https://doi.org/10.5897/ AJB2019.16947

- Mapiye C, Chimonyo M, Dzama K, Raats JG, Mapekula M (2008). Opportunities for improving Nguni cattle production in the smallholder farming systems of South Africa. Livest. Sci., 124: 196-204. https://doi.org/10.1016/j. livsci.2009.01.013

- Mbokodo I, Bopape M, Chikoore H, Engelbrecht F, Nethengwe $\mathrm{N}$ (2020). Heatwaves in the future warmer climate of South Africa. Atmosphere,11: 712. https://doi.org/10.3390/ atmos 11070712

-Mthembu NN, Zwane EM (2017). The adaptive capacity of smallholder mixed-farming systems to the impact of climate change: The case of KwaZulu-Natal in South Africa. Jàmbá, 9: 1-9. https://doi.org/10.4102/jamba.v9i1.469

-Paula-Lopes FF, Hansen PJ (2002). Heat shock induced apoptosis in preimplantation bovine embryos is a developmentally regulated phenomenon. Biol. Reprod., 66: 1169-1177. https://doi.org/10.1093/biolreprod/66.4.1169

- Payton RR, Rispoli LA, Nagle KA, Gondro C, Saxton AM, Voy BH, Edwards JL (2018). Mitochondrial-related consequences of heat stress exposure during bovine oocyte maturation persist in early embryo development. J. Reprod. Dev., https://doi.org/10.1262/jrd.2017-160

- Payton RR, Rispoli LA, Saxton AM, Edwards JL (2011). Impact of heat stress exposure during meiotic maturation on oocyte, surrounding cumulus cell, and embryo RNA populations. J. Reprod. Dev., 57:481-91. https://www.jstage.jst.go.jp > article > jrd >_pdf, https://doi.org/10.1262/jrd.10-163M

- Perry G (2018). 2016 Statistics of embryo collection and transfer in domestic farm animals. http://www.iets.org/pdf/ comm_data/IETS_Data_Retrieval_Report_2016_v2.pdf.

- Rojas-Downing MM, Nejadhashemi AP, Harrigan T, Woznicki SA (2017). Climate change and livestock: Impacts, adaptation, and mitigation. Clim. Risk Manage., 16: 145163. https://doi.org/10.1016/j.crm.2017.02.001

- Roth Z, Hansen PJ (2004). Involvement of apoptosis in disruption of developmental competence of bovine oocytes by heat shock during maturation. Biol. Reprod., 71: 18981906. https://doi.org/10.1095/biolreprod.104.031690
- Rynkowska A, Rąpała L, Trzeciak P, Duszewska A (2011). The application of in vitro cattle embryo production system to study the influence of elevated temperature on oocyte maturation, fertilization and early embryonic development. Biot. Comp. Biol. Bion., 92: 45-53. https://doi.org/10.5114/ bta.2011.46516

-Saeki A, Theeragool G, Matsushita K, Toyama H, Lotong N, Adachi O (1997). Development of thermotolerant acetic acid bacteria useful for vinegar fermentation at higher temperatures. Biosci. Biotech. Bioch., 61: 138-145. https:// doi.org/10.1271/bbb.61.138

-Sakatani M (2017). Effects of heat stress on bovine preimplantation embryos produced in vitro. J. Reprod. Dev., 63(4): 347-352. https://doi.org/10.1262/jrd.2017-045

-Sakatani M, Kobayashi S, Takahashi M (2004). Effects of heat shock on in vitro development and intracellular oxidative state of bovine preimplantation embryos. Mol. Reprod. Dev., 67: 77-82.https://doi.org/10.1002/mrd.20014

-Sakatani M, Yamanaka K, Ahmed ZB, Naoki T, Masashi T (2015). Heat stress during in vitro fertilization decreases fertilization success by disrupting anti- polyspermy systems of the oocytes. Mol. Reprod. Dev., 82: 36-47. https://doi. org $/ 10.1002 / \mathrm{mrd} .22441$

-SAS Institute (1999). Inc. SAS/STAT User's Guide Version $91^{\text {st }}$ printing, Volume 2. SAS Institute Inc, SAS Campus Drive, Cary North Carolina 27513.

-Scholtz MM, Maiwashe A, Magadlela MA, Tjelele TJ, Nkosi BD, Matabane M (2016). The reality of drought, consequences and mitigation strategies for livestock production in South Africa. Appl. Anim. Husb. Rural. Dev., 9: 6-10. https://www.sasas.co.za > AAHandRD

-Şen U, Kuran M (2018). Low incubation temperature successfully supports the in vitro bovine oocyte maturation and subsequent development of embryos. Asian Aust. J. Anim. Sci., 31(6): 827-834. https://doi.org/10.5713/ ajas.17.0569

-Seshoka MM, Mphaphathi ML, Nedambale TL (2016) Comparison of four different permitting and combination of two best cryoprotectants on freezing Nguni sperm evaluation with the aid of a computer aided sperm analysis. Cryobiology, 72: 232-238. https://doi.org/10.1016/j. cryobiol.2016.04.001

- Shapiro SS, Wilk MB (1965). An analysis of variance test for normality (complete samples). Biometrika, 52: 591-611. https://doi.org/10.1093/biomet/52.3-4.591

- Silva CF, Sartorelli ES, Castilho ACS, Satrapa RA, Puelker RZ, Razza EM, Ticianelli JS, Eduardo HP, Loureiro B, Barros CM (2013). Effects of heat stress on development, quality and survival of Bos indicus and Bos taurus embryos produced invitro. Theriogenology, 79: 351-357. https://doi. org/10.1016/j.theriogenology.2012.10.003

- Silvia FC, Lilian JO, Hansen PJ (2009). Repression of induced apoptosis in the 2- cell bovine embryo involves DNA methylation and histone deacetylation. Biochem. Biophys. Res. Commun., 388: 418-421. https://doi.org/10.1016/j. bbrc.2009.08.029

- Somal A, Aggarwal A, Upadhyay RC (2015). Effect of thermal stress on expression profile of apoptosis related genes in peripheral blood mononuclear cells of transition Sahiwal cow. Iran. J. Vet. Res., 16(2):137-143.

- Stamperna K, Giannoulis T, Nanas I, Kalemkeridou M, Dadouli K, Moutou K, Amiridis GS, Dovolou E (2020). Short term temperature elevation during IVM affects embryo yield and 
alters gene expression pattern in oocytes, cumulus cells and blastocysts in cattle. Theriogenology, 156: 36-45. https://doi. org/10.1016/j.theriogenology.2020.06.039

- Stamperna K, Giannoulis T, Dovolou E, Kalemkeridou M, Nanas I, Dadouli K, Moutou K, Mamuris Z, Amiridis GS (2021). Heat Shock Protein 70 Improves In Vitro Embryo Yield and Quality from Heat Stressed Bovine Oocytes. Animals., 11: 2-14. https://doi.org/ 10.3390/ani11061794. -van Wettere WHEJ, Kind KL, Gatford KL, Swinbourne AM, Leu ST, Hayman PT, Kelly JM, Weaver AC, Kleemann DO, Walker SK (2021). Review of the impact of heat stress on reproductive performance of sheep.J.Anim. Sci. Biotechnol., 12: 2-18. https://doi.org/10.1186/s40104-020-00537-z

-Wolfenson D, Roth Z (2019). Impact of heat stress on cow reproduction and fertility. Anim. Front., 9: 32-38. https:// doi.org/10.1093/af/vfy027 